\title{
Plant responses to fire in a Mexican arid shrubland
}

\author{
Dante Arturo Rodríguez-Trejo ${ }^{1 *}$ (D) Juli G. Pausas ${ }^{2}$ D, and Andrés Gelacio Miranda-Moreno ${ }^{1}$
}

\begin{abstract}
Background: Fire responses of species in arid environments have only been scarcely studied. We studied four species (Dasyliron lucidum Zucc., Juniperus deppeana Steud., Echinocactus platyacanthus Link \& Otto, and Agave potatorum Zucc.) in the Tehuacán-Cuicatlán Biosphere Reserve, Mexico. The objectives were to describe and quantify survival and resprouting, as well as the factors determining them, for the selected species. Six months after a 330 ha wildfire in 2014, 32 plots were established on three transects. Forest dasometric and fire severity variables were recorded. Logistic regression was utilized to obtain mortality and resprouting probability models, as well as linear regression to detect relationships among post- and pre-fire variables.

Results: All species had high survival rates (74.5 to 97.7\%). All surviving D. lucidum individuals resprouted apically. For $J$. deppeana, the probability of mortality was directly related to fire scar height on the trunk and inversely related to its diameter, whereas the probability of crown recovery was inversely related to the proportion of the tree height scorch. For E. platyacanthus, necrosed height was directly related to plant height. There was a positive relationship between basal area and the emission of new leaves for the A. potatorum.

Conclusions: In the different species, several traits that allowed high fire survival rates were observed (e.g., thick cortex or bark, fleshy non-flammable leaves, flammable leaves that reduce fire intensity, high volume to surface ratio). Many of these were primarily linked to drought resistance. All species gain fire resistance or tolerance as they increase in size. We concluded that the studied arid ecosystem of Mexico can withstand an altered or a base fire regime.
\end{abstract}

Keywords: arid zones, fire ecology, fire traits, Mexico

\section{Resumen}

Antecedentes: Las respuestas al fuego de especies en ambientes semiáridos han sido poco investigadas. Nosotros estudiamos cuatro especies (Dasyliron lucidum Zucc., Juniperus deppeana Steud., Echinocactus platyacanthus Link \& Otto, y Agave potatorum Zucc.) en la Reserva de la Biosfera Tehuacán-Cuicatlán, México. Los objetivos fueron describir y cuantificar la supervivencia y el rebrote, así como los factores que las determinan, para las especies seleccionadas. Seis meses después de un incendio de 330 ha en 2014, se establecieron 32 sitios sobre tres transectos. Se registraron variables dasométricas y de severidad del fuego. Se usó regresión logística para obtener modelos probabilísticos de mortalidad y rebrote, así como regresión lineal para detectar relaciones entre las variables previas y posteriores al fuego.

(Continued on next page)

\footnotetext{
* Correspondence: dantearturo@yahoo.com

${ }^{1}$ División de Ciencias Forestales, Universidad Autónoma Chapingo, km. 38.5

carretera México-Texcoco, C.P. 56230, Chapingo, Estado de México, Mexico

Full list of author information is available at the end of the article
} 
(Continued from previous page)

Resultados: Todas las especies tuvieron una alta supervivencia (74.5 a 97.7\%). Todos los individuos sobrevivientes de D. lucidum rebrotaron del ápice. En J. deppeana, la probabilidad de mortalidad estuvo directamente relacionada con la altura de la cicatriz de quemado sobre el tronco e inversamente relacionada con el diámetro, mientras que la probabilidad de recuperación de la copa estuvo inversamente relacionada con la proporción de la altura del árbol afectada por el fuego. Para E. platyacanthus, la altura de deshidratación estuvo directamente relacionada con la altura de la planta. Se halló una relación positiva entre el área basal y la emisión de nuevas hojas en A. potatorum.

Conclusiones: En las diferentes especies, se observaron varios caracteres que les permitieron una elevada tasa de supervivencia (como corteza o córtex gruesos, hojas carnosas no inflamables, hojas inflamables que reducen la intensidad del fuego y una alta relación volumen:superficie). Muchos de estos caracteres son primariamente adaptaciones a la sequía. Todas las especies ganaron resistencia o tolerancia al fuego conforme incrementaron su tamaño. Concluimos que el ecosistema árido de México estudiado se puede sostener en un régimen de fuego alterado o base.

\section{Introduction}

Fire and, more specifically, fire regimes have been a force that has shaped plants (Keeley et al. 2011), so many plant species in fire-prone ecosystems have adaptive strategies to persist under recurrent wildfires. Examples of ecosystems for which there is a good understanding of these strategies are the Mediterranean ones (Keeley et al. 2012) and savannas (Dantas et al. 2013, Charles-Dominique et al. 2015). However, little is known about fire tolerance strategies in arid ecosystem species where fire frequency is low due to fuel discontinuity and low fuel loadings (Bond 1983). Therefore, in these ecosystems, many species may not have evolved strategies for survival or regeneration in the face of fire and, consequently, they may be very sensitive to the current anthropogenic fire regime. However, in arid ecosystems, fires do occur, whether due to natural or human causes, and there is evidence of many plants surviving fire.

For succulent plants in arid zones, mainly cacti, morphological characteristics may serve as fire survival mechanisms. In this context, Thomas (1991) proposed that the following characteristics would help plants to survive fire: protection of the apical meristem with pilosities; compaction at the base of the leaves (rosetted); and insulation of the vascular tissue, thanks to a thick cortex. Bond (1983) showed that the degree of coverage of the persistent dead leaves on the Aloe ferox Mill. stem is negatively related to post-fire mortality due to leaves' insulating properties. Likewise, the protection of apical meristems, and thick and highly suberised bark confer fire tolerance in some succulent plants (e.g., Kumara plicatis [L.] G. Rowley in South Africa; Cousins et al. 2016). The low flammability of succulent plants has also been proposed as an adaptive mechanism for surviving low-intensity fire regimes (Pausas et al. 2017).

In species similar to those that we studied, physical traits in succulent plants give them some degree of survival in the case of fires. For example, there is evidence of some survival (between 3 and 50\%) in Dasylirion leiophyllum Engelm. ex Trel. and D. wheeleri S. Watson ex Rothr. after non-severe fires (Ahlstrand 1982, Wright and Bailey 1982, Thomas and Goodson 1992, Tesky 1993a, b). In Ferocactus wislizenii Britton \& Rose (SY = Echinocactus wislizenii Engelm.), older individuals have a thick cortex that insulates the vascular cambium from a fire's lethal temperatures, and its apical meristem is relatively high on the stem. Hence, individuals $>30 \mathrm{~cm}$ in height normally survive fires, while shorter individuals reach mortalities of $75 \%$ (Humphrey 1974, Matthews 1994). Regarding the Agave species, there is little information about their post-fire response; in some locations, scorching of $>50 \%$ of the leaves results in the death of the plant, but in others, all the leaves may have been scorched but the plant nonetheless recovers (Kittams 1973, Thomas 1991).

In arid ecosystems, non-succulent woody plants (trees and shrubs) also show some fire resistance. For example, Juniperus deppeana Steud. is considered fire resistant due to its high crown and relatively thick bark (Kittams 1973, Tirmenstein 1999); it shows low mortality even if it is burned by relatively severe fires (Rodríguez-Trejo 1996, 2014). This species has the ability to resprout after a fire from root-crown, lignotuber, and epicormic buds (Rodríguez-Trejo 2014, Pausas 2017). Fire scars on old trees show that they can survive large number of fires throughout their lives, although prescribed burns every 3 to 7 years can eliminate them (Moir 1982, Tirmenstein 1999). Other American species of that genus (e.g., Juniperus virginiana L., J. monosperma [Engelm.] Sarg., J. osteosperma [Torr.] Little, J. occidentalis Hook., J. flaccida Schltdl.) exhibit less fire resistance since they have thin bark, their buds are small, and they lack the ability to resprout (Miller 2000, Rodríguez-Trejo 2014).

In Mexican ecosystems, the role of fire is very noticeable (Rodríguez-Trejo 2008, 2014; Jardel-Pelaez et al. 2014; Pausas 2016), and many species in different types of ecosystems show strategies to persist in the face of fire. It is estimated that, in half of the 32 types of ecosystems, species with adaptive fire strategies prevail (Rodríguez-Trejo 2008, 2014). However, little is known about strategies in 
arid areas, which constitute a very important part of the country's biodiversity. The fire ecology in arid zones has received little attention worldwide and minimal attention in Mexico. To help fill this knowledge gap, we have studied four species (Dasyliron lucidum Zucc., Echinocactus platyacanthus Link \& Otto, Agave potatorum Zucc., and Juniperus deppeana) with highly contrasting morphological characteristics in the Tehuacán-Cuicatlán Biosphere Reserve, where fires are common at present (CONANP 2013). The three former species were chosen for their dominance in the rosetophilous shrubland (Fig. 1), while the latter species was dominant in the juniper forest. Specifically, the objectives of this research were to describe and quantify survival and resprouting, as well as the factors that determine them, for the four selected species; among the factors, forest dasometric and fire severity variables were considered. Our research will help us to understand the effect of fires on the diversity of these arid ecosystems.

\section{Methods}

\section{Study area}

The Tehuacán-Cuicatlán Biosphere Reserve covers 490187 ha in the states of Puebla and Oaxaca, Mexico. The study area hosts 21 ecosystem types; more than 3000 species of vascular plants, of which $12 \%$ are endemics, and 180 families have been recorded there, roughly representing $10 \%$ of vascular plant types for Mexico (CONANP 2013). One of the most important vegetation types there is the xeric shrubland, which covers $25 \%$ of the area. Of the four types of shrublands existing in the reserve, the one that covers the largest area is the rosetophilous shrubland (14.3\% of the reserve's total area, CONANP 2013), which includes Dasylirion lucidum stands (Rivera and Solano 2012). The study area was located amongst these stands, and also included Echinocactus platyacanthus and Agave potatorum on the slopes. Juniperus deppeana dominated the lower flat areas.

The study area was in an area of low mountains aligned from southwest to northeast, reaching 2400 to $2500 \mathrm{~m}$ a.s.l., surrounded by flat areas (around $2350 \mathrm{~m}$ a.s.l.). The area was formed by Cretacic sedimentary rocks. On the hills, the soils were litosols (CONANP 2013). The data from the meteorological station at Cuesta Blanca, Municipality of Palmar de Bravo, showed a mean temperature of $11.5^{\circ} \mathrm{C}$ and mean annual precipitation of $392 \mathrm{~mm}$ (for the period 2000 to 2014), falling mostly during the summer; the extreme annual precipitation levels were $133.2 \mathrm{~mm}$ (for 2005) and $569.5 \mathrm{~mm}$ (for 2008) (CICESE-CONACYT 2018). We visually estimated a surface fuel load of 2 to $4 \mathrm{t}$ $\mathrm{ha}^{-1}$ (no succulent plants were included).

Fires are not common in the reserve. During the period 2013 to 2016, 26 forest fires were recorded, with an average affected area of 33.3 ha (ranging from 1 to $330 \mathrm{ha}$ ), all on shrubland. Although the records are incomplete, the main cause of fire was related to livestock raising, and fires occurred in spring (CONANP 2013; CONANP, Tehuacán, Puebla, Mexico, unpublished report: reporte de incendios forestales [2013-2018]). No data on fire regime were available for the study area but, according to the authors' observations, the rosetophilous shrublands, dominated by Yucca L. species experienced relatively frequent spring surface fires (from every few years to every few decades). This regime is considered a

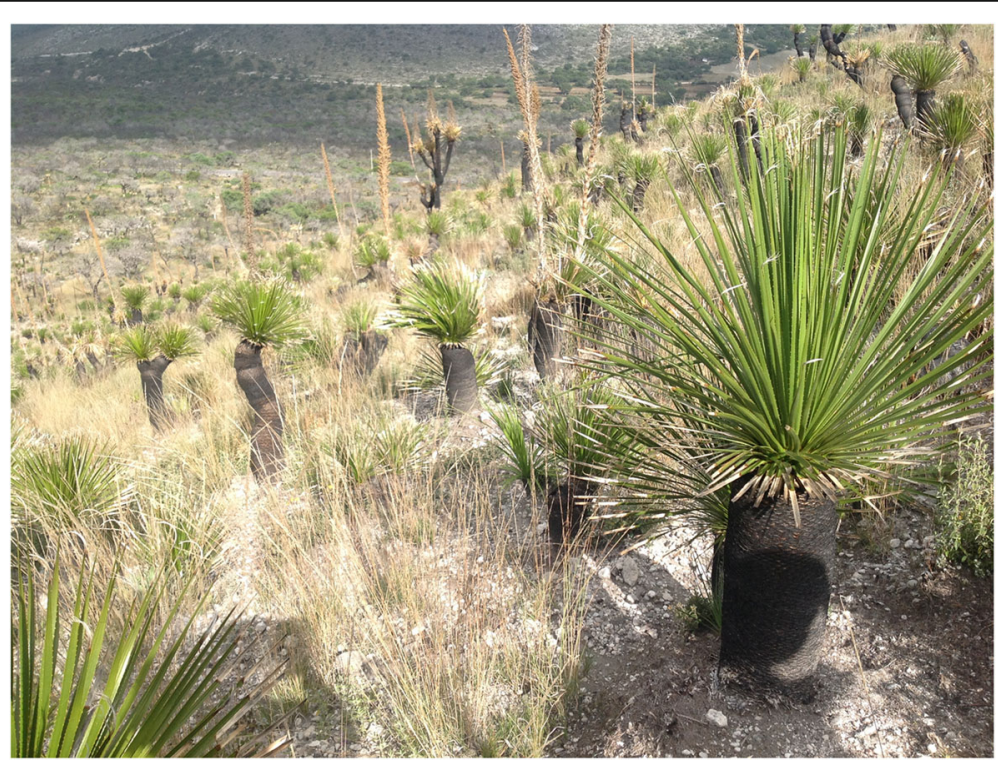

Fig. 1 Landscape view of the rosetophylous shrubland in the study zone on the Tehuacán-Cuicatlán Biosphere Reserve, state of Puebla, Mexico, in November 2014, six months after fire. Note the dominance of Dasylirion lucidum. In the background, note the juniper forest in the bottom of the valley. Photo credit: Dante Arturo Rodríguez-Trejo 
base fire regime, because despite it includes natural and human-ignited fires it maintains the integrity of the ecosystem. Where Dasylirion species were present, the fire regime included passive crown fires. CONANP (2013) points out that there were no reports of fires of natural origin in the reserve. In any case, we could not discard the possibility of natural fires given the long return periods (decades to centuries) that typify this type of shrubland in the United States (USFS 2012a, 2012b).

\section{Species}

We considered four species: Dasylirion lucidum (Asparagaceae), Juniperus deppeana (Cupressaceae), Echinocactus platyacantus (Cactaceae), and Agave potatorum (Asparagaceae). The three former species populate rocky limestone slopes with shallow and sandy soils. J. deppeana is a common tree species that usually grows on flat, deep, alluvial soils or on low slopes (Lesur 2011). Except for Juniperus deppeana, the species are endemic. Echinocactus platyacanthus is at risk, and under special protection. All species provide some use to the local population (as ornamental and medicinal plants, for wood, or for making beverages).

\section{Sampling}

In April 2014, a human-ignited wildfire occurred in the community of San Sebastián Coacnopalan, Municipality of Palmar de Bravo, within the Tehuacán-Cuicatlán Biosphere Reserve, state of Puebla, Mexico, on rosetophilous shrubland of Dasylirion lucidum on the hillsides, and Juniperus deppeana on the lower and flat parts. The fire covered $330 \mathrm{ha}$, mostly with an intense, passive crown fire (by which each individual's crown burns independently of the other crowns) in Dasylirion lucidum (M. Palma Martínez, Reserva de la Biosfera Tehuacán-Cuicatlán, Comisión Nacional de Áreas Naturales Protegidas, Tehuacán, Puebla, México, personal communication.)

Six months after the fire, a total of 32 plots were established on three transects in the affected area: two transects, each $240 \mathrm{~m}$ in length, with 12 plots sampled every $20 \mathrm{~m}$; and one transect $160 \mathrm{~m}$ in length, with 8 plots also sampled every $20 \mathrm{~m}$. Each plot consisted of a central point from which four quadrants (128 quadrants in total) were placed. From that point, the distance to the closest individual (of any of the four species) in each quadrant was measured. One of the transects (12 plots, 48 quadrants) was established in the stands of Dasylirion lucidum with Agave potatorum, between 2300 and $2400 \mathrm{~m}$ a.s.l., with SW and NE aspects; another transect was settled in stands of Juniperus deppeana (2250 $\mathrm{m}$ a.s.l., flat); and one more, selectively chosen for its patches of Echinocactus platyacanthus (with 8 plots, 32 quadrants, SW aspect, between 2300 and 2400 $\mathrm{m}$ a.s.l.). For each individual of the four species considered, the following variables were recorded, according to the plant life form: height, diameter at breast height and at the base, and crown diameter. In addition, for each individual, the severity of the fire (damage to trunk and crown) was evaluated. We recorded whether each was alive or dead, its stem char height, its lethal crown scorch height, the percentage of lethal crown scorch, and its scorch (necrosed) height. The scorched surface and green surface were recorded for Echinocactus platyacanthus. For A. potatorum, we measured: rosette diameter, proportion of leaves with $>50 \%$ dehydration, number of dead leaves, number of leaves with $<50 \%$ dehydration, and number of new leaves.

\section{Data analysis}

Means and intervals of density, diameter, and height were calculated, as well as mortality. To calculate the probability of mortality and resprouting, logistic mixed-model regression was used (Hosmer and Lemeshow 2000). The dasometric and fire severity (damage to trunk and crown) variables obtained in the sampling were used as independent variables individually and in combinations. These variables were considered with fixed effects, while the quadrants were considered with random effects. The $R$ program ( $R$ Core Team 2017) was used for modeling. In addition, linear regression was used to relate recovery variables to dasometric and fire severity variables.

\section{Results}

\section{Dasylirion lucidum}

Dasylirion lucidum was the most abundant species in the study area (Table 1). All individuals were fully scorched; that is, the whole height of the stem and all the foliage were burned. The average height at the base of the lowest (among 1 to 3 rosettes per individual) post-fire rosette was $0.6 \mathrm{~m}$, but some were $0.06 \mathrm{~m}$ high, which showed how easily the leaves were reached by surface fires. However, survival rate reached $97.7 \%$. This high survival rate did not lead to any modeling of this variable (Fig. 2a).

All surviving Dasylirion lucidum had vigorous, well-developed green rosettes, a product of the survival of the apical bud (often termed "apical resprouting"); the average crown area was $0.6 \mathrm{~m}^{2}(\mathrm{SD}=0.44)$. Plant height ( $H$, assuming that it was the same as before the fire) had a direct relationship with crown area $(S c)$ six months after fire; that is, taller plants generated a larger crown when resprouted (Fig. 3; Eq. 1; $\mathrm{R}^{2}=0.56, P<0.0001$ ).

$$
S c=-0.09062+0.77356 H
$$

Only $9.3 \%$ of individuals exhibited basal resprouts, and those had between 1 and 2 of them, with an average of 1.3 resprouts per individual. Many individuals flowered 
Table 1 Main characteristics of the four species studied on the Tehuacán-Cuicatlán Biosphere Reserve, state of Puebla, Mexico, in November 2014, indicating the number of individuals studied ( $n$ ), the density (individuals per $100 \mathrm{~m}^{2}$ ), the post-fire height (mean, standard deviation, and range; $\mathrm{m}$ ), the diameter (basal for Dasylirion lucidum, of rosette for A. potatorum, of the body for Echinocactus platyacanthus, and at breast height for Juniperus deppeana [mean and standard deviation; $\mathrm{cm}$ ]), and the mortality (in percentage of individuals)

\begin{tabular}{|c|c|c|c|c|c|c|c|}
\hline Species & $n$ & Density (plants per $100 \mathrm{~m}^{2}$ ) & Height (m) & Height range $(\mathrm{m})$ & Diameter (cm) & Diameter range $(\mathrm{cm})$ & Mortality (\%) \\
\hline Dasyliron lucidum & 34 & 28.6 & $0.91 \pm 0.41$ & 0.32 to 1.85 & $20.4 \pm 5.89$ & 9 to 33 & 2.3 \\
\hline Agave potatorum & 30 & 17.6 & $0.27 \pm 0.11$ & 0.05 to 0.47 & $32.7 \pm 14.3$ & 11 to 70 & 10.0 \\
\hline Echinocactus platyacanthus $^{\mathrm{a}}$ & 20 & 2.1 & $0.67 \pm 0.25$ & 0.21 to 1.40 & $47.8 \pm 12.4$ & 28 to 78 & 4.8 \\
\hline Juniperus deppeana $^{\mathrm{b}}$ & 47 & 1.8 & $4.22 \pm 1.47$ & 0.85 to 6.30 & $22.0 \pm 10.7$ & 5 to 55 & 25.5 \\
\hline
\end{tabular}

Within the colonies and patches that it forms

${ }^{b}$ In the low valleys where it is found

after the fire, but so did the Dasylirion lucidum that were outside the burned area. Therefore, no relationship was found between fire and flowering.

\section{Juniperus deppeana}

Juniperus deppeana had a low density, although it was the tallest species in the study area (Table 1). The crown diameter was between 0.9 and $12 \mathrm{~m}$ (mean $=4.36 \mathrm{~m}, \mathrm{SD}=$ 2.05); $25.5 \%$ of the trees were recorded as dead after the fire. Technical personnel of the reserve reported no evident tree mortality in this area prior to fire. Stem char height reached

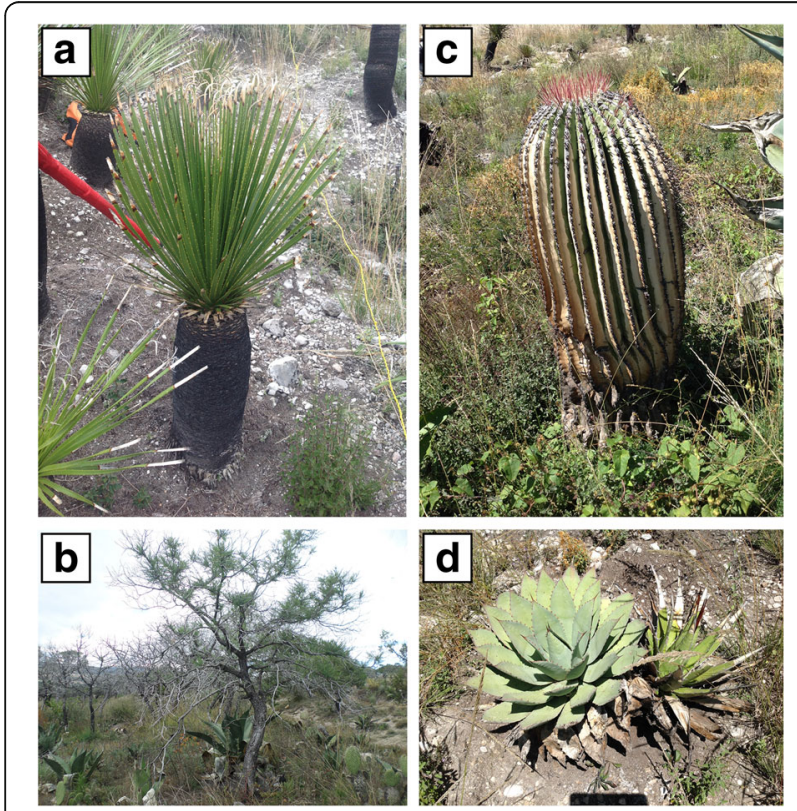

Fig. 2 a Dasylirion lucidum showing crown recovery after fire. The tips of the leaves look burned or dehydrated because they were beginning to emerge at the time of the fire. $\mathbf{b}$ Some Juniperus deppeana dead after the fire and others with epicormic resprouts. $\mathbf{c}$ Dehydration and growth of green tissue between the tubers (ribs) of Echinocactus platyacanthus. d Agave potatorum and Agave peacockii Croucher after fire. Photos were taken six months after fire on the Tehuacán-Cuicatlán Biosphere Reserve, state of Puebla, Mexico, in November 2014. Photo credit for photos $\mathbf{a}, \mathbf{c}$, and $\mathbf{d}$ : Dante Arturo Rodríguez-Trejo. Photo credit for photo b: José Daniel Luna-Fontés from 0.15 to $5.8 \mathrm{~m}$, with an average of $2.61 \mathrm{~m}(\mathrm{SD}=1.23)$. Lethal crown scorch height reached up to $5.8 \mathrm{~m}$, with an average of $3.14 \mathrm{~m}(\mathrm{SD}=1.31)$. The percentage of crown recovery ranged from null to $90 \%$, with an average of $37.6 \%$ (SD = 34.6; Fig. 2b).

Of the surviving trees, $55.2 \%$ showed some sign of resprouting at the base of the trunk, with an average of 5.3 resprouts per tree (among those that resprouted). The resprouts were 2 to $50 \mathrm{~cm}$ long, with a mean of $17.8 \mathrm{~cm}$.

Regarding the probability of mortality, the most robust model was with the explanatory variables stem char height and diameter at breast height. The probability of mortality $\left(P_{\mathrm{M}}\right)$ increased with scar height on the trunk $(T)$, and with the reduction in the diameter at breast height ( $D$; Fig. 4; Eq. 2; Table 2).

$$
P_{\mathrm{M}}=\frac{1}{1+\exp -(-1.70058+2.06797 T-0.27006 D)}
$$

The probability of resprouting $\left(P_{\mathrm{R}}\right)$ had an inverse relationship with scorch height $\left(A_{\mathrm{A}}\right.$; expressed as a percentage of the

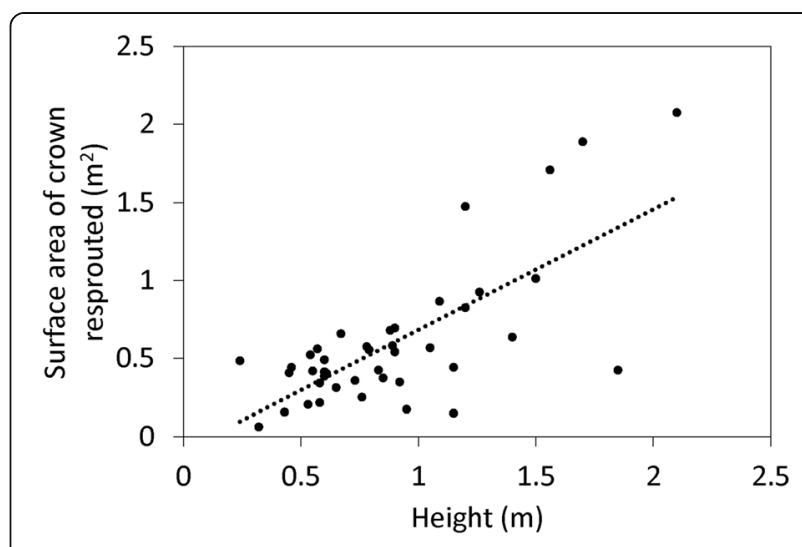

Fig. 3 Relationship between the height of the plant and the resprouted crown area six months after fire on the Tehuacán-Cuicatlán Biosphere Reserve, state of Puebla, Mexico, in November 2014. Each point represents a sampled individual 

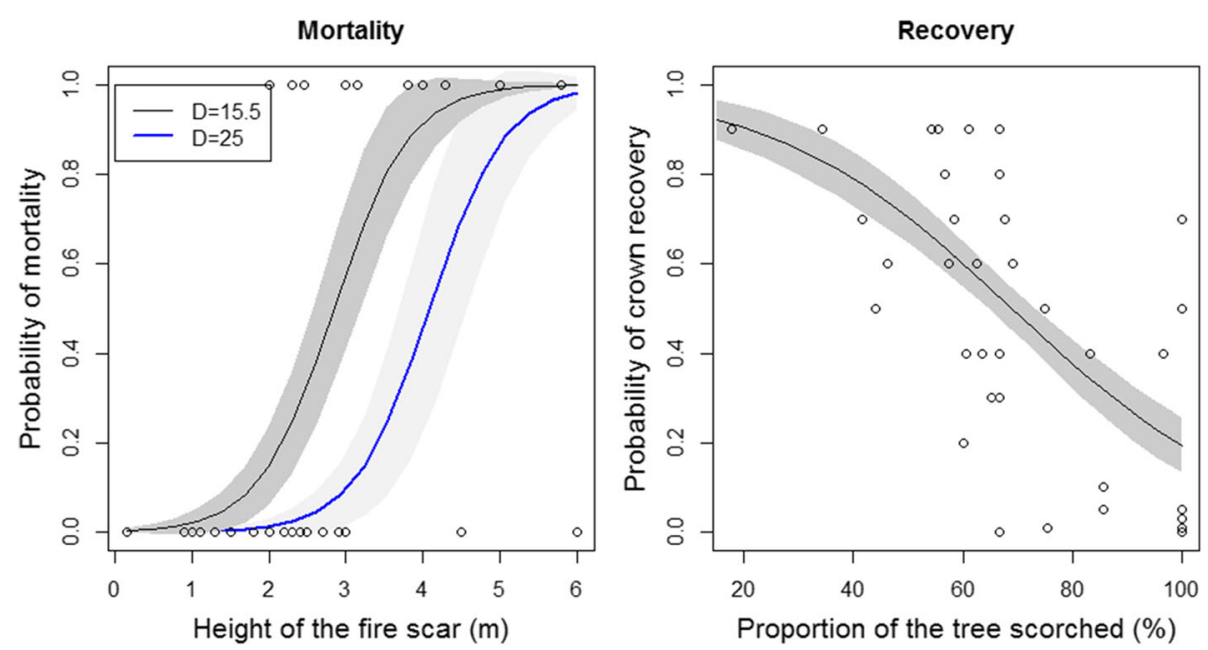

Fig. 4 Probability of mortality and probability of crown recovery of Juniperus deppeana six months after fire on the Tehuacán-Cuicatlán Biosphere Reserve, in November 2014. Mortality is a function of the height of the fire scar and the diameter, and crown recovery is determined by the proportion of the tree that was scorched by fire. See Table 2 for details. $\mathrm{D}=$ diameter at breast height

height of the tree). As the proportion of the affected height increased, with respect to the height of the tree, the likelihood of crown recovery decreased (Fig. 4; Eq. 3; Table 2).

$$
P_{\mathrm{R}}=\frac{1}{1+\exp -\left(2.584-0.041 A_{\mathrm{A}}\right)}
$$

\section{Echinocactus platyacanthus}

Echinocactus platyacanthus was not abundant. It had the largest stem diameter of the four species (Table 1). The average individual coverage of this cactus reached $0.19 \mathrm{~m}^{2}$ ( $\mathrm{SD}=0.24$; Fig. $2 \mathrm{c}$ ). Cactus mortality was $4.8 \%$. However, at the time of evaluation, the vigor of these plants was poor. New green tissues were observed in the inner part between the ribs of all the surviving cacti, representing $5 \%$ of the surface of the plants. No resprouts of any kind were found. The maximum and minimum

Table 2 Summary of the mixed models for mortality and crown recovery for Juniperus deppeana in the study sites on the Tehuacán-Cuicatlán Biosphere Reserve, state of Puebla, Mexico, in November 2014. The last column provides the intercept and coefficients of the fixed effects for the final model. See also Fig. 4

\begin{tabular}{lcccr}
\hline & AIC & Chi-square & $P$ value & Coeff \\
\hline Mortality & & & & \\
$\quad$ Null & 56.364 & & & -1.700 \\
Fire scar height & 47.393 & 10.970 & 0.00092 & 2.067 \\
$\quad$ Diameter & 32.538 & 16.855 & 0.00004 & -0.270 \\
Crown recovery & & & & \\
$\quad$ Null & 1075.6 & & & 2.584 \\
Scorch height & 834.3 & 243.3 & $<0.00001$ & -0.041 \\
\hline
\end{tabular}

scorch heights were $1.30 \mathrm{~m}$ and $0.13 \mathrm{~m}$, respectively, with the mean equal to $0.53 \mathrm{~m}(\mathrm{SD}=0.25)$. Thus, an average of $89.1 \%$ of the height of these cacti was necrosed by the fire. Plant height $(H)$ was positively related to the average necrosed height $\left(H_{\mathrm{N}} ;\right.$ Eq. $\left.4 ; \mathrm{R}^{2}=0.87 ; P<0.0001\right)$.

$$
H_{\mathrm{N}}=-0.12114+0.96543 H
$$

\section{Agave potatorum}

Agave potatorum was a relatively abundant species (Table 1). Its average mortality was $10 \%$. Almost all living A. potatorum individuals sprouted and continued to sprout new leaves from the plant's central axis. On average, there were 27.3 dead leaves, including partial leaves, per individual. However, it was not possible to discern how many of these died directly as a result of the fire and how many from natural or other causes before the fire. There was an average of four leaves with $\geq 50 \%$ fire damage, as well as 4.4 leaves with $<50 \%$ fire damage, per plant. The average number of new leaves (not affected) was 10.1. There was post-fire shoot resprouting in only $3.3 \%$ of the individuals (Fig. 2d). A linear trend was observed in which as the agaves were larger (with a greater basal area, $B A$ ), they sprout a greater number of new leaves $(N L)$ in the center (Fig. 5; Eq. 5; $\mathrm{R}^{2}=0.64 ; P<0.0001$ ).

$$
N L=0.91003+0.04995 B A
$$

\section{Discussion}

Different species have different traits that confer survival in the face of fire (Table 3). Such strategies are not 


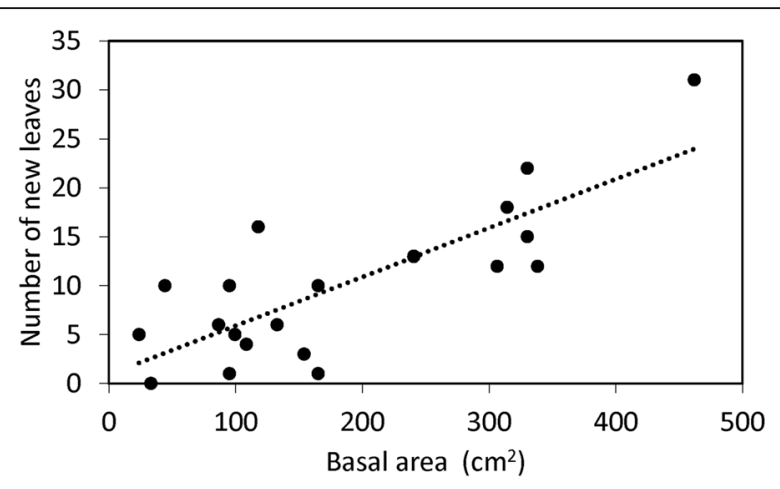

Fig. 5 Direct relationship between the basal area of the agaves and the emission of new leaves after fire on the Tehuacán-Cuicatlán Biosphere Reserve, state of Puebla, Mexico, in November 2014

exclusive responses to fire, as many serve primarily to withstand drought. Traits such as succulent leaves, high volume to surface ratio (approximately 2 versus 0.02 in broadleaf trees), and a thick cuticle (up to $20 \mu \mathrm{m}$, compared to up to $6 \mu \mathrm{m}$ in broad-leaved trees) (Nobel 1998) decrease flammability and facilitate fire resistance in Agave species. The bulk at the base of the fleshy leaves also increases the volume to surface ratio and can help insulate the apical meristem and the caudex of the agave from high temperatures during fires. This characteristic is also observed in rosethophilous arborescent species, such as Aloe ferox Mill. in South Africa, whose dry leaves insulate the stem from the heat of combustion because they are not very flammable (Bond 1983). It should be added that, in Agave, the external leaves are the oldest and with the highest volume to surface ratio, enabling them to act as a barrier that insulates these plants from the heat they receive during fires, particularly if the outermost layers of leaves tend to be raised. The tips of the leaves usually dehydrate the most compared to the rest of the leaf, but the tips recover after damage from fire. It can be expected that Agave species with thicker, longer, and more abundant leaves receive less damage from fire, which increases their chances of survival (Fig. 4d). In addition, Thomas (1991) and Gucker (2006) report that Agave lechuguilla Torr. has sufficient root depth $(10 \mathrm{~cm}$, according to Nobel and Quero 1986) to survive a fire's lethal temperatures, although we do not know this factor for A. potatorum of the study area.

On the other hand, the dry leaves of Dasylirion lucidum on the stem are highly flammable (Rodríguez-Trejo 2014), but when burned quickly they probably generate low fire intensity at the base, and the apical bud survives (Gagnon et al. 2010, Pausas et al. 2017). Along with the short height of this species, the dry leaves provide vertical continuity so that the surface fire reaches the crowns of these plants. Recovery is achieved by the growth of the original bud (apical resprouting). As a consequence, almost all individuals survived.

Thermal insulation of the vascular cambium by bark or cortex is another characteristic that allows survival in many species (Wright and Bailey 1982, Pausas 2015). According to Dickison (2000), the genus Dasylirion has a type of cambium called a thickening ring. The cortex and the perennial base of the leaves provide heat insulation to this tissue. The relatively thick bark of Juniperus deppeana provides resistance to fire (Kittams 1973, Tirmenstein 1999), but resistance is reduced in both dry years (Steuter and Wright 1983) and in the drier environments of its natural range. During dry years, moisture limitation can reduce productivity, vigor, and the regenerative capacity of fire-damaged tissues, such as their photosynthetic ability. In very dry environments, productivity is reduced, which should result in thinner trees with thinner bark and, therefore, with reduced vascular cambium protection. Even the lowest crown can facilitate a higher level of damage during a fire.

Damage caused by fire in some species can increase mortality months and years after its passage. In Juniperus deppeana, the higher the damage to the trunk and the smaller the diameter, the greater the probability of mortality. Likewise, the higher that the level of damage to the crown is, the less the resprouting. In several temperate-zone species, for example Quercus crassifolia Humb \& Bonpl, the greater that the damage to the crown is, the better the resprouting of the base (Juárez-Bravo et al. 2012), because when the crown is affected, auxins, phytohormones that inhibit resprouting, are eliminated, while the cytokinins in the root stimulate this resprouting response (Miller 2000). The scarce resprouting of Juniperus deppeana may be due to

Table 3 Main characteristics that confer fire resistance or fire tolerance to the four species studied on the Tehuacán-Cuicatlán Biosphere Reserve, state of Puebla, Mexico, in November 2014. Empty cells = "No."

\begin{tabular}{|c|c|c|c|c|}
\hline Trait & D. lucidum & E. platyacanthus & A. potatorum & J. deppeana \\
\hline Thick cortex or bark & Yes & Yes & & Yes \\
\hline Fleshy, non-flammable leaves & & & Yes & \\
\hline Protected apical buds & Yes & Yes & Yes & \\
\hline Flammable leaves that reduce fire intensity & Yes & & & \\
\hline High volume to surface ratio & & Yes & Yes & \\
\hline Bank of buds on the stem and root crown & & & & Yes \\
\hline
\end{tabular}


the limited moisture in the study area, which reduces productivity, recovery from damage, and resprouting.

The thick cortex in the cactus not only prevents dehydration, but it also helps it resist fire. The cortex of Echinocactus platyacanthus insulates phloem and cambium from the heat of the fire. As the cactus grows, its apical meristem becomes higher and the base of the ribs develops a bark (Thomas 1991, Matthews 1994). For some Dasylirion species, such as Dasylirion lucidum, if the fire causes cambial death, it can cause the death of individuals, although some are considered more sensitive, such as Dasylirion wheeleri (Ahlstrand 1982, Tesky 1993b).

In Ferocactus wislizenii, insects, drought, and browsing by rodents, lagomorphs, and livestock interact with fire to determine mortality. The loss of spines by fire in these cacti eliminates their defense against herbivores, and herbivores tend to consume more plants with succulent tissues in drier years. Therefore, fire, drought, and damage by herbivores affect survival (Thomas 1991). Drought adaptations such as spines and apical pubescence of columnar and biznaga cacti protect apical meristem from excessive heating and frost damage. Spines and pubescence can reduce the temperature at this area by about $14{ }^{\circ} \mathrm{C}$ (Nobel 1998). If a fire eliminates spines and apical pubescence in Echinocactus platyacanthus, more damage and post-fire mortality can be expected.

In some cases, the plants studied were located next to or in stony areas where fuel load was low. This helped to reduce the fire's intensity and severity, as in many arid zones (Thomas 1991), and makes a refuge for some plants (refugia strategy, Pausas 2019). It must also be taken into account that 2014 was a wet year, with precipitation of $559.6 \mathrm{~mm}$, while the precipitation for 2012 and 2013 was 357.2 and $485 \mathrm{~mm}$, respectively (precipitation data from CICESE-CONACYT 2018). Such higher humidity availability may have facilitated post-fire resprouting and survival in the studied species. Drier years may show weaker and slower post-fire responses and lower survival.

\section{Conclusions}

In conclusion, most plants studied survive after a fire (mortality $<30 \%$, Table 1 ), although with different mechanisms (Table 3), and all gained fire resistance or tolerance as they increased in age and size. Therefore, it seems that this arid ecosystems of Mexico resist a certain fire regime. To what extent an increase in fire activity may reduce resilience remains to be studied. However, it seems that very frequent fires, particularly during dry years, may increase mortality, especially in cacti and Agave. Less frequent fires may not increase the intensity or severity of fires or fire-related mortality very much because of the low precipitation that limits productivity and fuel accumulation.

\section{Acknowledgements}

The authors thank the Tehuacán-Cuicatlán Biosphere Reserve (CONANP) and biologists F. Reyes-Flores and M. Palma-Martínez, officials of the Reserve, for their logistical support. We thank G. Mendoza-Ángeles, J.D. Luna-Fontés, J.

Rupit-Morteno, and E. Palafox for their support in the field. The authors thank R. Paradice for the translation (Spanish to English) of the manuscript and technical editing of the Spanish to English translation. We thank the anonymous peerreviewers for their thoughtful work that helped to improve ours.

\section{Funding}

Funding for this study was provided in part by Fondo Mexicano para la Conservación de la Naturaleza, USDA Forest Service, US Agency for International Development, Universidad Autónoma Chapingo (Ajusco Project on Fire Ecology, Fire Management and Restoration of Burnt Areas), and FOCSEC Project (PROMETEO/2016/21), on the role of fire and aridity in plant communities.

\section{Availability of data and materials}

Please contact corresponding author for data requests.

\section{Authors' contributions}

DART conceived and designed the experiment, coordinated the field work, conducted field sampling, performed statistical analysis, and participated in the writing of the manuscript and technical editing of the Spanish to English translation. JGP participated in field work, performed statistical analysis, and participated in the writing of the manuscript, and in the technical editing of the English to Spanish translation of it. AGMM was responsible for species identification, and helped with the writing of the manuscript and technical editing of the Spanish to English translation. All authors read and approved the final manuscript.

\section{Ethics approval and consent to participate Not applicable.}

\section{Consent for publication \\ Not applicable.}

\section{Competing interests}

The authors declare that they have no competing interests.

\section{Publisher's Note}

Springer Nature remains neutral with regard to jurisdictional claims in published maps and institutional affiliations.

\section{Author details}

'División de Ciencias Forestales, Universidad Autónoma Chapingo, km. 38.5 carretera México-Texcoco, C.P. 56230, Chapingo, Estado de México, Mexico. ${ }^{2}$ Centro de Investigaciones sobre Desertificación, Consejo Superior de Investigaciones Científicas (CIDE-CSIC), Carretera CV-315, km. 10.7, 46113 Montcada, Valencia, Spain.

Received: 7 August 2018 Accepted: 28 January 2019

\section{References}

Ahlstrand, G.M. 1982. Response of Chihuahuan Desert mountain shrub vegetation to burning. Journal of Range Management 35: 62-65. https://doi. org/10.2307/3898521

Bond, W.J. 1983. Dead leaves and fire survival in southern African tree aloes. Oecologia 58: 110-114. https://doi.org/10.1007/BF00384549

Charles-Dominique, T., H. Beckett, G.F. Midgley, and W.J. Bond. 2015. Bud protection: a key trait for species sorting in a forest-savanna mosaic. New Phytologist 207: 1052-1060. https://doi.org/10.1111/nph.13406

CICESE-CONACYT [Centro de Investigación Científica y de Educación Superior de Ensenada-Consejo Nacional de Ciencia y Tecnología]. 2018. CICESE-CONACYT homepage. http://ciclom-mex.cicese.mx/. Accessed 1 Nov 2018.

CONANP [Comisión Nacional de Áreas Naturales Protegidas]. 2013. Programa de Manejo. Reserva de la Biosfera Tehuacán-Cuicatlán. Secretaría de Medio Ambiente y Recursos Naturales, CONANP, Ciudad de México, México. [n Spanish.] 
Cousins, S.R., E.T.F. Witkowski, and M.F. Pfab. 2016. Beating the blaze: fire survival in the fan aloe (Kumara plicatilis), a succulent monocotyledonous tree endemic to the Cape fynbos, South Africa. Austral Ecology 41: 466-479. https://doi.org/10.1111/aec.12318

Dantas, V.L., J.G. Pausas, M.A. Batalha, P.P. Loiola, and M.V. Cianciaruso. 2013. The role of fire in structuring trait variability in Neotropical savannas. Oecologia 171: 487-494. https://doi.org/10.1007/s00442-012-2431-8

Dickison, W.C. 2000. Integrative plant anatomy. Cambridge: Academic Press.

Gagnon, P.R., H.A. Passmore, W.J. Platt, J.A. Myers, C.E.T. Paine, and K.E. Harms. 2010. Does pyrogenicity protect burning plants? Ecology 91: 3481-3486. https://doi.org/10.1890/10-0291.1

Gucker, C.L. 2006. Fire Effects Information System: Agave lechuguilla. https:// www.fs.fed.us/database/feis/plants/shrub/agalec/all.html. Accessed 23 May 2006.

Hosmer, D.W., and S. Lemeshow. 2000. Applied logistic regression. New York: Wiley https://doi.org/10.1002/0471722146

Humphrey, R.R. 1974. Fire in the desserts and dessert grassland of North America. In Fire and ecosystems, ed. T.T. Kozlowski and C.E. Ahlgren, 365-400. New York: Academic Press https://doi.org/10.1016/B978-0-12-424255-5.50016-X

Jardel-Pelaez, E., D. Pérez-Salicrup, E. Alvarado-Celestino, and J.E. Morfín-Ríos. 2014. Principios y criterios para el manejo del fuego en ecosistemas forestales: guía de campo. Comisión Nacional Forestal, Guadalajara, Jalisco, México. [ln Spanish.]

Juárez-Bravo, J.E., D.A. Rodríguez-Trejo, and R.L. Myers. 2012. Fire tolerance of three tree species in pine-oak forests of Chignahuapan, Puebla, Mexico. International Journal of Wildland Fire 21: 873-881. https://doi.org/10.1071/ WF11134

Keeley, J.E., W.J. Bond, R.A. Bradstock, J.G. Pausas, and P.W. Rundel. 2012. Fire in Mediterranean ecosystems: ecology, evolution and management. Cambridge: Cambridge University Press.

Keeley, J.E., J.G. Pausas, P.W. Rundel, W.J. Bond, and R.A. Bradstock. 2011. Fire as an evolutionary pressure shaping plant traits. Trends in Plant Science 16: 406411. https://doi.org/10.1016/j.tplants.2011.04.002

Kittams, W.H. 1973. Effect of fire on vegetation of the Chihuahuan Desert region. Pages 427-444 in: Proceedings of the annual Tall Timbers fire ecology conference, 8-9 June 1972, Lubbock, Texas, USA. Fire Ecology Conference Proceedings Volume 12, Tall Timbers Research Station, Tallahassee, Florida, USA. Lesur, L. 2011. Árboles de México. Trillas, Ciudad de México, México. [In Spanish.] Matthews, R.F. 1994. Fire Effects Information System: Ferocactus wislizeni. https:// www.fs.fed.us/database/feis/plants/cactus/ferwis/all.html. Accessed 21 Sept 2016.

Miller, M. 2000. Fire autecology. Pages 9-34 in: J.K. Brown and J. Kapler Smith, editors. Wildland fire in ecosystems. Volume 2: effects of fire on flora. USDA Forest Service General Technical Report RMRS-GTR-42, Rocky Mountain Research Station, Ogden, Utah, USA.

Moir, W.H. 1982. A fire history of the high Chisos, Big Bend National Park, Texas. The Southwest Naturalist 27: 87-98. https://doi.org/10.2307/3671411

Nobel, P.S. 1998. Los incomparables agaves y cactos. Trillas, Ciudad de México, México. [In Spanish.]

Nobel, P.S., and E. Quero. 1986. Environmental productivity indices for a Chihuahuan Desert CAM plant, Agave lechuguilla. Ecology 67: 1-11.

Pausas, J.G. 2015. Bark thickness and fire regime. Functional Ecology 29: 317-327. https://doi.org/10.1111/1365-2435.12372

Pausas, J.G. 2016. Flammable Mexico. International Journal of Wildland Fire 25: 711-713. https://doi.org/10.1071/WF16018

Pausas, J.G. 2017. Juniperus deppeana postfire. http://jgpausas.blogs.uv.es/2017/ 11/18/. Accessed 15 Dec 2017.

Pausas, J.G. 2019. Generalized fire response strategies in plants and animals. Oikos 128: 147-153. https://doi.org/10.1111/oik.05907

Pausas, J.G., J.E. Keeley, and D.W. Schwilk. 2017. Flammability as an ecological and evolutionary driver. Journal of Ecology 105: 289-297. https://doi.org/10.1111/ 1365-2745.12691

R Core Team. 2017. R: a language and environment for statistical computing. R Foundation for Statistical Computing, Vienna. (http//www.R-project.org/).

Rivera, L.M., and E. Solano. 2012. Flora del valle de Tehuacán-Cuicatlán. Fascículo 99. Nolinaceae Nakae. Instituto de Biología, Universidad Nacional Autónoma de México, Ciudad de México, México. [In Spanish.]

Rodríguez-Trejo, D.A. 1996. Incendios forestales. Mundi Prensa, Universidad Autónoma Chapingo, Instituto Nacional de Investigaciones Agropecuarias y Forestales, Ciudad de México, México. [In Spanish.]
Rodríguez-Trejo, D.A. 2008. Fire regimes, fire ecology and fire management in Mexico. Ambio 37: 548-556. https://doi.org/10.1579/0044-7447-37.7.548

Rodríguez-Trejo, D.A. 2014. Incendios de vegetación. Su ecología, manejo e historia. Volume 1. Editorial Colegio de Postgraduados, Universidad Autónoma Chaping., Secretaría de Medio Ambiente y Recursos Naturales, Comisión Nacional Forestal, Comisión Nacional de Áreas Naturales Protegidas, Guadalajara, Jalisco, México. [In Spanish.]

Steuter, A.A., and H.A. Wright. 1983. Spring burning to manage redberry juniper rangelands-Texas Rolling Plains. Rangelands 5: 249-251.

Tesky, J.L. 1993a. Fire Effects Information System: Dasylirion leiophyllum. https://www. fs.fed.us/database/feis/plants/shrub/daslei/all.html Accessed 9 Sept 2016.

Tesky, J.L. 1993b. Fire Effects Information System: Dasylirion wheeleri. https://www. fs.fed.us/database/feis/plants/shrub/daswhe/all.html Accessed 9 Sept 2016.

Thomas, P.A. 1991. Response of succulents to fire: a review. International Journal of Wildland Fire 1: 11-22. https://doi.org/10.1071/WF9910011

Thomas, P.A., and P. Goodson. 1992. Conservation of succulents in desert grasslands managed by fire. Biological Conservation 60: 91-100. https://doi. org/10.1016/0006-3207(92)91159-P

Tirmenstein, D. 1999. Fire Effects Information System: Juniperus deppeana. https:// www.fs.fed.us/database/feis/plants/tree/jundep/all.html Accessed 9 Sept 2016.

USFS [US Forest Service]. 2012a. Fire Effects Information System Information: fire regimes of Southwestern desert grasslands. https://www.fs.fed.us/database/ feis/fire_regimes/SW_desert_grass/all.html Accessed 24 Apr 2018.

USFS [US Forest Service]. 2012b. Fire Effects Information System Information: fire regimes of Chihuahuan Desert scrub communities. https://www.fs.fed.us/ database/feis/fire_regimes/Chihuahuan_desert_scrub/all.html Accessed 24 Apr 2018.

Wright, H.A., and A.W. Bailey. 1982. Fire ecology. United States and southern Canada. New York: Wiley.

\section{Submit your manuscript to a SpringerOpen ${ }^{\circ}$ journal and benefit from:}

- Convenient online submission

- Rigorous peer review

- Open access: articles freely available online

- High visibility within the field

- Retaining the copyright to your article

Submit your next manuscript at $\boldsymbol{\sim}$ springeropen.com 